\title{
TINGKAT KEPUASAN KONSUMEN TERHADAP PROSEDUR LAYANAN POS UNTUK BARANG KENA PAJAK DAN ATAU BEA CUKAI DI KANTOR POS BATAM CENTRE
}

\author{
Afrianto \\ Dwi Kartika sari, S.T., M.B.A \\ Prodi Administrasi Bisnis Terapan \\ Politeknik Negeri Batam \\ Tel/HP : 0812-3277-7870 \\ Email: afrianto1993@gmail.com
}

\begin{abstract}
Abstrak
Penelitian ini bertujuan untuk mengetahui tingkat kepuasan konsumen terhadap prosedur layanan pos untuk barang kena pajak dan atau Bea Cukai di Kantor Pos Batam Centre. Kepuasan Konsumen merupakan hasil akhir yang dirasakan oleh pengguna produk atau jasa, baik itu kurang, sama atau melebihi harapan yang dinginkan. Dengan menggunakan statistik deskriptif menghasilkan tingkat kepuasan konsumen terhadap prosedur yang ada di Kantor Pos Batam Centre untuk pengiriman barang yang terkena pajak oleh bea cukai rata-rata berada pada daerah positif jika diukur dengan tabel interprestasi, itu artinya konsumen yang memakai jasa kantor pos mendapakan pelayanan memuaskan dari setiap prosedur yang ada di Kantor Pos Batam Centre.
\end{abstract}

Kata Kunci : Kepuasan Konsumen, Prosedur Layanan, Kantor Pos

\section{Latar Belakang}

Indonesia dikenal sebagai Negara kepulauan yang memiliki ratusan juta jumlah penduduk. Untuk dapat menjalankan roda pemerintahan sertamemenuhi kebutuhan dasar penduduknya dibutuhkan pengalokasian biaya yang ditampung melalui APBN (Anggaran Pendapatan dan Belanja Negara). Salah satu penyumbang dana terbesar bagi APBN yaitu melalui kegiatan ekspor impor. Badan atau instansi yang melakukan pemungutan bea masuk dan bea keluar melalui kegiatan ekspor impor ini adalah Direktorat Jenderal Bea dan Cukai di bawah pengawasan Kementerian Keuangan. Salah satu kantor Direktorat Jenderal Bea dan Cukai yang melayani jasa ekspor impor yaitu Kantor Pengawasan dan Pelayanan Bea dan Cukai Tipe B yang berada di Kantor Pos Batam Centre.

Kantor Pengawasan dan Pelayanan Bea Cukai Tipe B di kantor Pos Batam Centre merupakan salah satu kantor biasa Direktorat Jenderal Bea dan Cukai yang berada di wilayah Batam. Kantor Pelayanan Utama Bea dan Cukai Tipe B Batam merupakan gabungan dari Kantor Pengawasan dan Pelayanan Bea dan Cukai Tipe A3 Batam, Tipe A3 Muka Kuning dan Tipe D Sekupang. Wilayah kerja Kator Pelayanan Utama Tipe B Batam meliputi Pulau Batam Seluas $415 \mathrm{~km}^{2}$. Sementara batas wilayah kerja Kantor Pelayanan Utama Bea dan Cukai Tipe B Batam yaitu Singapura (Barat Laut), Pulau Bintan (Timur) dan Malaysia (Utara). Mengingat wilayah kerja yang cukup luas dan meliputi seluruh pulau, maka Kantor Pelayanan Utama
Tipe B Batam memiliki 12 Kantor Bantu Pelayanan Bea Cukai dan Pos Pengawasan Bea Cukai atau biasa disebut hanggar yang tersebar di Pulau Batam. Hanggar tersebut ditempatkan di pelabuhan lait dan udara yang ditunjuk sebagai KPBPB (Kawasan Perdagngan Bebas dan Pelabuhan Bebas), yaitu Pelabuhan Peti Kemas Batu Ampar, Pelabuhan Sarana Citranusa Kabil/PT. SembCorp Logistics Citra Nusa, Pelabuhan Kawasan Industri Sewu/Beton Sekupang dan Pelabuhan Udara Hang Nadim (sumber:http://bcbatam.beacukai.go.id/ruanglingkup/).

Selain di Kawasan Perdagangan Bebas dan Pelabuhan Bebas tersebut, hanggar Kantor Pelayanan Utama Bea dan Cukai Tipe B Batam juga berada di Kantor Pos Lalu Bea Batam Center dan pelabuhan laut resmi yang memperoleh izin dari Kementerian Perhubungan. Kantor Pengawasan dan Pelayanan Bea dan Cukai Tipe Batam biasa atau hanggar bea cukai, melaksanakan penyelesaian barang impor atau barang kena pajak melalui kiriman pos setelah mendapat mandat dari menteri keuangan.

Sesuai Surat Keputusan Menteri Keuangan Nomor 21/WBC.11/2008 tanggal 18 Februari 2008 tentang Penetapan Kantor Pos Batam Centre Sebagai Kawasan Pemungutan Bea Masuk di Tempat lain. Kantor Pos yang 
memiliki wewenang untuk melakukan pemeriksaan ekspor impor dinamakan Kantor Pos Lalu Bea. Pegawai yang ditempatkan di Kantor Pos Lalu Bea Batam Centre Merupakan pegawai Kantor Pengawasan dan Pelayanan Bea dan Cukai Tipe B dan pegawai Kantor Pos Batam Centre yang bekerja sama melaksanakan tugas dan fungsi untuk melakukan pemeriksaan barang ekspor impor dan memungut bea masuk dan bea keluar sebagai penerimaan negara.

Meski telah mendapat banyak penghargaan di bidang pelayanan terbaik, pelayanan Kantor Pos Lalu Bea Batam Centre dalam melayani kegiatan ekspor impor diketahui terdapat beberapa permasalahan. Seperti banyaknya konsumen yang mengeluh terkait adanya kurangnya informasi mengenai prosedur dan peraturan barang yang dikenakan pajak dan bea cukai. Hal ini karena minimnya pengetahuan masyarakat mengenai barang kena pajak dan bea cukai melalui jasa pos. Penulis berharap skripsi ini dapat menjembatani kebutuhan masyarakat akan informasi prosedur barang kena pajak dan bea cukai melalui jasa pos serta memberikan informasi terhadap tingkat kepuasan konsumen jasa pos khususnya konsumen layanan pos untuk barang kena pajak atau bea cukai.

\section{Identifikasi dan Perumusan Masalah}

Berdasarkan latar belakang penelitian yang telah dijelaskan diatas maka, dirumuskan masaalah sebagai berikut :

1. Bagaimana tingkat kepuasan konsumen terkait prosedur layanan pos yang melibatkan barang kena pajak dan atau bea cukai di Kantor Pos Batam Centre?

2. Hal-hal apa saja yang diharapkan konsumen terhadap prosedur layanan pos yang melibatkan barang kena pajak dan atau bea cukai di Kantor Pos Batam Centre?

3. Apa saja solusi yang diharapkan dapat meningkatkan tingkat kepuasan konsumen terhadap prosedur layanan pos yang melibatkan barang kena pajak dan atau bea cukai di Kantor Pos Batam Centre?

\section{Tujuan Penelitian}

Adapun tujuan dari penelitian adalah sebagai berikut:

1. Adapun yang menjadi tujuan dari penelitian ini sebagai berikut : Untuk mengetahui bagaimana tingkat kepuasan konsumen terkait prosedur layanan pos yang melibatkan barang kena pajak dan atau bea cukai di Kantor Pos Batam Centre

2. Untuk mengetahui hal-hal apa saja yang diharapkan konsumen terhadap prosedur layanan pos yang melibatkan barang kena pajak dan atau bea cukai di Kantor Pos Batam Centre

3. Untuk mengetahui apa saja solusi yang diharapkan dapat meningkatkan tingkat kepuasan konsumen terhadap prosedur layanan pos yang melibatkan barang kena pajak dan atau bea cukai di Kantor Pos Batam Centre?

\section{Manfaat Penelitian}

Manfaat yang diharapkan dari penelitian ini adalah dapat menjadi informasi tambahan dan juga masukan bagi Kantor Pos Batam Centre, tentang bagaimana dan sejauh mana tingkat pelayanan Kantor Pos Batam Centre terkait prosedur barang kena pajak. Sejauh ini tidak semua masyrakat mengetahui prosedur barang kena pajak yang ingin memakai jasa pengiriman di Kantor Pos Batam Centre. Penulis juga berharap menemukan solusi untuk meningkatkan kepuasan pelanggan di Kantor Pos Batam Centre.

\section{Kajian Pustaka \\ Prosedur}

Prosedur penting dimiliki bagi suatu organisasi agar segala sesuatu dapat dilakukan secara seragam. Pada akhirnya prosedur akan menjadi pedoman bagi suatu organisasi dalam menentukan aktivitas apa saja yang harus dilakukan untuk menjalankan suatu fungsi tertentu. Untuk lebih jelasnya mengenai pengertian prosedur menurut beberapa para ahli: Prosedur (procedure) didefinisikan oleh Lilis Puspitawati dan Sri Dewi Anggadini (2011) dalam buku yang berjudul "Sistem Informasi Akuntansi"sebagai berikut: "Serangkaian langkah/kegiatan klerikal yang tersusun secara sistematis berdasarkan urutanurutan yang terperinci dan harus diikuti untuk dapat menyelesaikan suatu permasalahan". Menurut Mulyadi (2010) dalam bukunya yang berjudul "Sistem Akuntansi" mengemukakan bahwa: "Prosedur adalah urutan kegiatan klerikal, biasanya melibatkan beberapa orang dalam suatu departemen atau lebih, yang dibuat untuk menjamin penanganan secara seragam transaksi perusahaan yang terjadi berulang”.

\section{Prosedur Barang Kena Pajak}

Setiap barang kiriman pos atau layanan pos yang terkena pajak oleh bea cukai, memiliki prosedur tersendiri dari kiriman biasanya. Barang kiriman pos yang dikenakan pajak adalah barang kiriman pos yang melebihi FOB USD 50.00 (lima puluh US dollar) untuk setiap orang per alamat kiriman. Terhadap barang kiriman pos yang melebihi nilai tersebut dikenakan bea masuk dan pajak dalam rangka impor atas nilai kelebihannya. Dalam hal ini terdapat petunjuk adanya penyalahgunaan fasilitas pembebasan tersebut atau pengiriman yang berulang-ulang untuk satu orang dan/atau alamat yang sama dalam tempo 1(satu) hari, terhadap barang kiriman pos tersebut dengan tidak memperhatikan nilai dan/atau jumlahnya 
dikenakan Bea Masuk dan pajak dalam rangka impor. Dasar hukum atau undang-undang yang memuat peraturan barang kiriman pos kena pajak adalah:

1. Keputusan Menteri Keuangan No. 490/KMK.05/1996 tentang Tata laksana Impor Barang Penumpang, Awak Sarana Pengangkut, Pelintas Batas, Kiriman Pos, dan Kiriman Melalui Jasa Titipan.

2. Keputusan Dirjen Bea dan Cukai No. KEP78/BC/1997 tentang Petunjuk Pelaksanaan Penyelesaian Barang Penumpang, Awak Sarana Pengangkut, Pelintas Batas, Kiriman Melalui Jasa Titipan dan Kiriman Pos.

3. Keputusan Bersama Dirjen Bea dan Cukai dengan Dirjen Postel No. KEP-80a/BC/1997 dan No. 208/DIRJEN/1997 tentang Penyelesaian Barang Impor atau Barang Ekspor yang Dikirim Melalui Pos

4. Surat Edaran Bersama Dirjen Bea dan Cukai denga Dirut PT. Pos Indonesia (Persero) No. SE33b/BC/1997dan No. 133/Dirutpos/1997 tentang Tatacara Penyelesaian Barang Impor atau Barang ekspor yang Dikirim Melalui Pos dengan Menggunakan Jasa Express Mail Service (EMS).

5. Surat Edaran Bersama Dirjen Bea dan Cukai denga Dirut PT. Pos Indonesia (Persero) No. SE33a/BC/1997dan No. 132/Dirutpos/1997 tentang Tata cara Penyelesaian Barang Kiriman Melalui Pos Dari Kawasan Berikat (Bonded Zone) daerah Industri Pulau Batam yang Dikirim Ke Dalam Daerah Pabean Indonesia Lainnya. Dan adapula barang kiriman pos yang dikenakan pajak tetapi memiliki persyaratan tertentu seperti:

1. Telepon Seluler, Komputer Genggam, dan Komputer Tablet melebihi 2 (dua) unit per kiriman harus mendapatkan ijin sebagai Importir TerdaftardarKemendag(Permendag Nomor 82/M-DAG/PER/12/2012).

2. Senjata Api/Angin/Mainan/Replika bagian maupun aksesorisnya, Crossbow, Bahan peledak dan Peralatan Keamanan Lainnya harus dilengkapi ijin dari Kapolri (PU 20/1960 jo. Kep. KAPOLRI No. Skep/82/II/2004 Jo.R/13/I/2005).

3. Obat, Obat Tradisional, Suplemen dan produk pangan olahan harus dilengkapi ijin dari BPOM/Kemenkes.

4. Barang-barang bekas harus dilengkapi ijin dari Kemendag (Permendag 54/M DAG/PER/10/2009).

5. Tumbuhan dan Hewan harus dilengkapi dengan Sertifikat Pelepasan dari Balai Karantina (PP 14 Tahun 2002 Tentang Karantina Tumbuhan dan PP 8 tahun 2000 tentang Karantina Hewan).

6. Produk tertentu berupa : pakaian paling banyak 10 pcs perkiriman;elektronika paling banyak 2 pcs, produk tertentu lainnya (Makanan, minuman, Obat Tradisional, Suplemen Kosmetik, Alas Kaki, Mainan anak anak) paling banyak senilai FOB USD $1.500,00$, lebih dari itu harus dilengkapi ijin dari Kemendag

7. SNI terhadap beberapa produk seperti Mainan anak-anak Pelek, Ban, Helm dan lain-lain.

8. Alat Kesehatan harus dilengkapi ijin dari Kemenkes (Dasar Hukum Permenkes No. 1190/MENKES/PER/VIII/20 10).

\section{Kepuasan Pelanggan}

Kepuasan pelanggan pada dasarnya berhubungan dengan tingkat perasaan seseorang setelah membandingkan kinerja atau hasil yang ia rasakan dengan harapannya Menurut Jasfar (2006), kepuasan pelanggan terhadap suatu jasa adalah perbandingan antara persepsinya terhadap jasa yang diterima dengan harapannya sebelum menggunakan jasa tersebut. Apabila harapannya terlampaui, berarti jasa tersebut telah memberikan suatu kualitas yang luar biasa dan akan menumbulkan kepuasan sangan tinggi. Sebaliknya, jika harapannya tidak tercapai, maka diartikan kualitas jasa tersebut tidak memenuhi apa yang diingikannya atau perusahaan tersebut gagal melayani pelanggannya. Apabila harapannya sama dengan apa yang dia peroleh, berarti pelanggan puas.

\section{Kualitas Layanan}

Menurut Tjipto (2006), kualitas merupakan kodisi dinamis yang berhubungan dengan produk, jasa, manusia, proses dan lingkungan yang memenuhi atau melebihi harapan. Sehingga defenisi kualitas pelayanan dapat diartikan sebagai upaya pemenuhan kebutahan dan keinginan konsumenserta ketepatan penyampaiannya dalam mengimbangi harapan konsumen. Menurut Sunyoto (2012), kualitas layanan terdiri dari lima variabel yaitu tangible (atribut yang tampak), reliability (dapat diandalkan), assurance (jaminan atau kemampuan dipercaya), empathy (kepedulian) dan responsiveness (daya tanggap).

\section{Kerangka Penelitian}

Kerangka pemikiran adalah sebuah pemahaman yang melandasi pemahamanpemahaman lainnya. Kerangka pemikiran digunakan untuk memperjelas gambaran isi penelitian. Kerangka dari penelitian ini adalah sebagai berikut: 


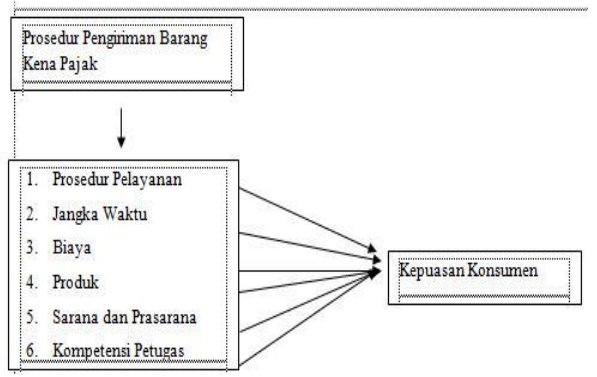

Gambar : 2.2 Kerangka Penelitian

(Sumber : Pengolahan Data, 2017)

\section{Metode Penelitian \\ Rancangan Penelitian}

Rancangan penelitian menggunakan jenis penelitian deskriptif kuantitatif. Pada penelitian ini mengarah pada pendeskripsian secara kuantitatif mengenai tata cara/prosedur pengiriman barang kena pajak dan atau bea cukai di

Kantor Pos Batam Centre, perhitungan kepuasan konsumennya, hal-hal yang diharapkan oleh konsumen, serta alternatif solusi untuk meningkatkan kepuasan konsumen.

\section{Objek dan Ruang Lingkup Penelitian}

Objek dalam penelitian ini adalah prosedur dan tingkat kepuasan konsumen layanan pos untuk barang kena pajak dan atau bea cukai. Adapun ruang lingkup penelitian ini yaitu hanya layanan yang diberikan kantor pos pada konsumen atas barang yang kena pajak dan atau bea cukai saja

\section{Populasi dan Sampel Populasi}

Menurut Sugiyono (2013), populasi adalah wilayah generalisasi yang terdiri dari atas: objek/subjek yang mempunyai kualitas dan karakteristik tertentu yang diterapkan oleh peneliti untuk dipelajari dan kemudian ditarik kesimpulannya. Dalam penelitian ini yang menjadi populasi adalah masyarakat yang berada di Batam.

\section{Sampel}

Sampel. Menurut Sugiyono (2015), sampel adalah subset dari populasi, terdiri dari beberapa anggota populasi. Pengambilan sampel dilakukan dengan pertimbangan bahwa populasi yang ada sangat besar jumlahnya, sehingga tidak memungkinkan untuk meneliti seluruh populasi yang ada, sehingga dibentuk sebuah perwakilan populasi. Metode pengambilan sampel yang digunakan adalah Accidental Sampling Method yaitu pengambilan sampel yang dilakukan secara acak. Perwakilan populasi yang dijadikan sampel adalah konsumen layanan pos atas barang kena pajak dan atau cukai yang berada di kantor pos Batam Centre yang kebetulan ditemui pada saat melakukan pem Besarnya jumlah populasi dalam penelitian ini tidak dapat ditetapkan karena jumlah konsumen yang kantor pos batam centre tidak dapat diketahui maka pengambilan sampel

mengggunakan rumus sebagai berikut: $\mathrm{n}=96,04 \approx 97$ atau dibulatkan menjadi
100 orang
Dimana $:$
$\mathrm{n}=$ Jumlah Sampel

$\mathrm{Z}=$ Nilai $\mathrm{Z}$ dengan tingkat keyakinan yang dibutuhkan penentuan sampel persen, Pada $\alpha=5 \%, Z=1.96$ Moe = Margin of Error, atau tingkat kesalahan maksimum yang bisa ditoleransi Jadi sampel yang akan digunakan

adalah sebanyak 100 orang konsumen Kantor Pos Batam Centre.

\section{Teknik Pengumpulan Data}

Terdapat dua hal utama yang mempengaruhi kualitas data hasil penelitian, yaitu kualitas instrumen penelitian, dan kualitas pengumpulan data. Kualitas instrumen penelitian berkenaan dengan validitas dan reliabilitas instrumen dan kualitas pengumpulan data berkenaan ketepatan caracara yang digunakan untuk mengumpulkan data (Sugiyono, 2015). Teknik pengumpulan data yang dilakukan dalam penelitian adalah melalui:

1. Kuisioner

2. Observasi

\section{Jenis dan Sumber Data}

Penggunaan sumber data dalam penelitian sangatlah penting karena ketepatan dalam memilih dan menentukan jenis dan sumber data akan menentukan kekayaan data atau informasi yang diperoleh. Adapun jenis dan sumber data yang digunakan dalam penelitian ini adalah data primer dan data sekunder.

\section{Data Primer}

Data yang diperoleh atau dikumpulkan oleh peneliti secara langsung dari sumber datanya, Kuncoro (2004). Data primer dalam penelitian ini diperoleh dari kuisioner yang disebarkan kepada

konsumen yang melakukan pengiriman barang kena pajak dan atau bea cukai. Data primer juga diperoleh dari wawancara secara langsung kepada staf Kantor Pos Batam Centre untuk mengidentifikasi alternatif solusi dari harapan yang disampaikan oleh konsumen.

\section{Data Sekunder}

Data ini diperoleh dengan menggunakan studi dokumen yang dilakukan terhadap banyak buku dan diperoleh berdasarkan catatan-catatan yang berhubungan dengan penelitian, selain itu peneliti mempergunakan data yang diperoleh dari internet (Sugiyono, 2005). Data sekunder disebut juga sebagai data asli atau data baru yang memiliki sifat up to date (Kuncoro, 2004). 
Data sekunder yang diperoleh dalam penelitian ini seperti profil organisasi/instansi,strukturorganisasi/instansi, data jumlah karyawan yang berada di kantor Pos Batam

\section{Metode Analisis Data}

Metode analisis data adalah proses pengumpulan data secara sistematis untuk mempermudah peneliti dalam memperoleh kesimpulan. Dalam penelitian kuantitatif ini, analisis data merupakan suatu kegiatan yang dilakukan setelah data dari seluruh responden atau sumber data lain terkumpul. Kegiatan yang dilakukan dalam dalam analisis data ini adalah mengelompokkan data berdasarkan variabel dan jenis responden, menyajikan data tiap variabel yang diteliti, menyajikan data tiap variabel yang diteliti, dan melakukan

perhitungan untuk menjawab rumusan masalah adalah sebagai berikut :

\section{Analisis Statistik Deskriptif}

Statistik deskriptif adalah statistik yang digunakan untuk menganalisis data dengan cara mendeskripsikan atau menggambarkan data yang telah terkumpul sebagaimana adanya tanpa bermaksud membuat kesimpulan yang berlaku untuk umum atau generalisasi (Sugiyono, 2015).

\section{Validitas dan Reliabilitas Uji Validitas}

Uji validitas digunakan untuk mengukur sah (valid) atau tidaknya suatu kuesioner. Suatu kuesioner dikatakan valid jika pertanyaan dalam kuesioner mampu untuk mengungkap sesuatu yang akan diukur oleh kuesioner tersebut. Uji validitas dihitung dengan membandingkan nilai $r$ hitung (correlation item - total correlation) dengan nilai $r$ tabel. Jika $r$ hitung $>r$ tabel dan nilai positif maka butir atau pertanyaan tersebut dinyatakan valid (Ghozali, 2005). Kriteria penilaian uji validitas yang digunakan adalah sebagai berikut:

a. Apabila $r_{\text {hitung }}>r_{\text {tabel }}$, maka dapat

dikatakan item kuesioner tersebut valid

b. Apabila $r_{\text {hitung }}<r_{\text {tabel }}$, maka dapat

Dikatakan item kuesioner tersebut tidak valid.

Sedangkan menurut Sugiyono (2011), kriteria uji validitas yang digunakan sebagai berikut:

a. Jika $r_{\text {positif, }}$ serta $r \geq 0,30$, maka item pertanyaan tersebut valid

b. Jika $r_{\text {negatif }}$ atau $\leq 0,30$, maka item pertanyaan tersebut tidak valid.

Rumus untuk menentukan validitas adalah sebagai berikut:

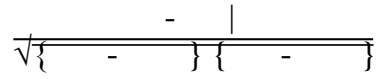

\section{Rumus Korelasi Product Moment}

Keterangan:

$r_{x y}=$ koefisien korelasi antara skor tiap item dengan skor total item

$$
\begin{array}{ll}
\Sigma_{\mathrm{x}} & =\text { jumlah skor tiap item } \\
\Sigma_{\mathrm{y}} & =\text { jumlah skor total item } \\
\mathrm{n} & =\text { jumlah sampel }
\end{array}
$$

\begin{tabular}{|c|c|c|c|c|c|}
\hline \multirow{2}{*}{$\begin{array}{c}\text { Variabe } \\
l\end{array}$} & \multicolumn{5}{|c|}{ Validitas } \\
\hline & $\begin{array}{c}\text { Ite } \\
\text { m }\end{array}$ & $\begin{array}{c}\mathbf{r} \\
\text { Hitun } \\
\mathbf{g} \\
\text { Perse } \\
\text { psi }\end{array}$ & $\begin{array}{c}\mathbf{r} \\
\text { Hitun } \\
\mathbf{g} \\
\text { Harap } \\
\text { an }\end{array}$ & $\begin{array}{c}\text { r } \\
\text { Tab } \\
\text { el }\end{array}$ & $\begin{array}{c}\text { Keteran } \\
\text { gan }\end{array}$ \\
\hline \multirow{3}{*}{$\begin{array}{l}\text { Prosedur } \\
\text { Layanan }\end{array}$} & $\begin{array}{c}\text { Ite } \\
\mathrm{m} \\
1\end{array}$ & 0,761 & 0,919 & \multirow{3}{*}{$\begin{array}{c}0,19 \\
5\end{array}$} & Valid \\
\hline & $\begin{array}{l}\text { Ite } \\
\mathrm{m} \\
2\end{array}$ & 0,857 & 0,807 & & Valid \\
\hline & $\begin{array}{c}\text { Ite } \\
\mathrm{m} \\
3\end{array}$ & 0,696 & 0,705 & & Valid \\
\hline \multirow{2}{*}{$\begin{array}{l}\text { Jangka } \\
\text { Waktu }\end{array}$} & $\begin{array}{l}\text { Ite } \\
\mathrm{m} \\
4\end{array}$ & 0,874 & 0,852 & $\begin{array}{c}0.19 \\
5\end{array}$ & Valid \\
\hline & $\begin{array}{c}\text { Ite } \\
\mathrm{m} \\
5\end{array}$ & 0,812 & 0,886 & & Valid \\
\hline \multirow{2}{*}{ Biaya } & $\begin{array}{c}\text { Ite } \\
\mathrm{m} \\
6\end{array}$ & 0,857 & 0,964 & \multirow[t]{2}{*}{0.19} & Valid \\
\hline & $\begin{array}{c}\text { Ite } \\
\mathrm{m} \\
7\end{array}$ & 0,873 & 0,933 & & Valid \\
\hline \multirow{2}{*}{ Produk } & $\begin{array}{c}\text { Ite } \\
\mathrm{m} \\
8\end{array}$ & 0,878 & 0,803 & \multirow[t]{2}{*}{0.19} & Valid \\
\hline & $\begin{array}{c}\text { Ite } \\
\text { m } \\
9\end{array}$ & 0,867 & 0,934 & & Valid \\
\hline \multirow{2}{*}{$\begin{array}{c}\text { Sarana } \\
\text { dan } \\
\text { Prasaran } \\
\text { a }\end{array}$} & $\begin{array}{c}\text { Ite } \\
\mathrm{m} \\
10\end{array}$ & 0,878 & 0,910 & \multirow{2}{*}{$\begin{array}{c}0.19 \\
5\end{array}$} & Valid \\
\hline & $\begin{array}{c}\text { Ite } \\
\mathrm{m}\end{array}$ & 0,906 & 0,914 & & Valid \\
\hline
\end{tabular}

Adapun hasil uji validitas dengan menggunakan SPSS 17.00. for windows adalah sebagai berikut: 


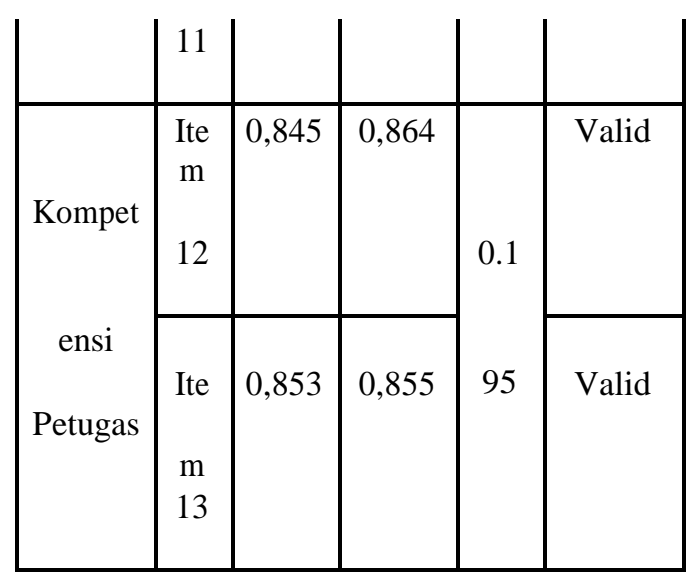

Dari hasil pengujian validitas pada tabel 3.3 diatas, dapat diketahui bahwa nilai $r$ hitung seluruh pernyataan antara persepsi dan

harapan pada masing-masing variabel yaitu variabel prosedur layanan, jangka waktu, biaya, produk, sarana dan prasarana dan kompetensi petugas dengan $r$ hitung lebih besar $r$ tabel yaitu 0.195, sehingga dapat ditarik kesimpulan bahwa seluruh butir pernyataan dinyatakan lolos uji validitas dan dinyatakan layak digunakan sebagai alat ukur dalam penelitian ini

\section{Uji Reliabilitas}

Instrumen yang reliabilitas adalah instrumen yang jika kita dapat menjamin hasil yang konsisten atas pengukuran yang dilakukan berulang kali atas orang yang sama dengan instrumen yang sama Cooper

\& Schinder, (2006). Bila koefisien korelasi (r) positif dan signifikan, maka instrumen tersebut sudah dinyatakan reliabel. Ketentuan untuk pengambilan keputusan reliabilitas adalah sebagai berikut:

1. Jika nilai Cronbach Alpha > 0,60 (Ghazali, 2006 ), maka pertanyaan tersebut dinyatakan reliabel.

2. Jika nilai Cronbach Alpha <,0,60 (Ghazali, 2006 ), maka pertanyaan tersebut dinyatakan tidak reliable

Adapun rumus Alpha Cronbach (Riduwan, 2007) adalah:

\section{Keterangan :}

$\alpha=$ Koefisien alpha cronbach

$\mathrm{r}=$ Rata-rata korelasi diantara butir

pertanyaan

$\mathrm{k}=$ Jumlah butir pertanyaan dalam

skala

Untuk hasil pengujian reliabilitas pada penelitian ini dapat dilihat melalui tabel dibawah ini dengan hasil sebagai berikut:

\begin{tabular}{|l|c|c|c|}
\hline \multirow{2}{*}{ Variabel } & \multicolumn{2}{|c|}{$\begin{array}{c}\text { Crombacth's } \\
\text { Alfa }\end{array}$} & \multirow{2}{*}{ Keterangan } \\
\cline { 3 - 4 } & Persepsi & Harapan & \\
\hline $\begin{array}{l}\text { Prosedur } \\
\text { Layanan }\end{array}$ & 0.660 & 0,687 & Reliabel \\
\hline $\begin{array}{l}\text { Jangka } \\
\text { Waktu }\end{array}$ & 0.731 & 0,675 & Reliabel \\
\hline Biaya & 0.664 & 0,869 & Reliabel \\
\hline Produk & 0.686 & 0,642 & Reliabel \\
\hline $\begin{array}{l}\text { Sarana dan } \\
\text { Prasarana }\end{array}$ & 0,742 & 0,798 & Reliabel \\
\hline $\begin{array}{l}\text { Kompetens } \\
\text { i } \\
\text { Petugas }\end{array}$ & 0,615 & 0,646 & Reliabel \\
\hline
\end{tabular}

Sumber : Pengolahan Data (2017)

Berdasarkan tabel 3.4 diatas, dapat ditarik kesimpulan bahwa dari ke Enam variabel yaitu variabel prosedur layanan, jangka waktu, biaya, produk, sarana dan prasarana dan kompetensi petugas mendapat nilai Cronbach's Alfha $>0,60$, sehingga keempat variabel penelitian tersebut dinyatakan reliabel.

\section{Hasil Penelitian}

\section{Karakteristik Koresponden}

Responden dalam penelitian ini adalah konsumen layanan pos atas barang kena pajak dan atau cukai yang berada di kantor pos Batam Centre, berdasarkan data dari 100 responden yang merupakan konsumen layanan pos atas barang kena pajak melalui daftar pertanyaan didapat kondisi responden mengenai jenis kelamin, usia, pendidikan dan pekerjaan. Penggolongan yang dilakukan terhadap responden dalam penelitian ini bertujuan untuk mengetahui secara jelas mengenai gambaran responden sebagai objek penelitian. Karakteristik responden berdasarkan pengelompokan akan dijabarkan sebagai berikut :

\section{Karakterisrik Responden Berdasarkan Jenis Kelamin}

Analisis karakteristik responden berdasarkan kelompok jenis kelamin sebagai berikut: 
Tabel 4.1 Karakteristik Responden Berdasarkan Jenis Kelamin

\begin{tabular}{|l|c|c|}
\hline \multicolumn{1}{|c|}{$\begin{array}{c}\text { Jenis } \\
\text { Kelamin }\end{array}$} & Frekuensi & Persentase \\
\hline Laki-laki & 57 & $57 \%$ \\
\hline Perempuan & 43 & $43 \%$ \\
\hline Total & 100 & $100 \%$ \\
\hline
\end{tabular}

Berdasarkan data pada Tabel 4 diatas, dapat diketahui bahwa jumlah responden laki-laki sebanyak 57 orang dengan presentase $57 \%$ dan jumlah responden perempuan sebanyak 43 orang dengan presenase $43 \%$. Berdasarkan data tersebut, dapat disimpulkan bahwa responden laki-laki lebih banyak dibandingkan responden perempuan.

Karakteristik Responden Berdasarkan Usia Hasil analisis karakteristik responden berdasarkan kelompok Usia sebagai berikut:

Tabel 4.2 Karaktersistik Responden Berdasarkan Usia

\begin{tabular}{|c|c|c|}
\hline $\begin{array}{c}\text { Usi } \\
\text { a }\end{array}$ & Frekuensi & Persentase \\
\hline $\begin{array}{l}<20 \\
\text { Tahun }\end{array}$ & 26 & $26 \%$ \\
\hline $\begin{array}{l}21-30 \\
\text { Tahun }\end{array}$ & 31 & $31 \%$ \\
\hline $\begin{array}{l}31-40 \\
\text { Tahun }\end{array}$ & 22 & $22 \%$ \\
\hline $\begin{array}{l}41-50 \\
\text { Tahun }\end{array}$ & 17 & $17 \%$ \\
\hline $\begin{array}{l}51-60 \\
\text { Tahun }\end{array}$ & 4 & $4 \%$ \\
\hline Total & 100 & $100 \%$ \\
\hline
\end{tabular}

Sumber: Data Olahan SPSS

Berdasarkan data pada Tabel

4.2 diatas, dapat diketahui bahwa jumlah responden yang usia $<20$ Tahun sebanyak 26 orang dengan presentase $26 \%$, jumlah responden dangan usia antara 21 - 30 Tahun sebanyak 31 orang dengan presentase $31 \%$, jumlah responden dengan usia 31 - 40 Tahun sebanyak 22, jumlah responden dengan usia $41-50$ Tahun sebanyak 17 orang dengan presentase $17 \%$ dan jumlah responden dengan usia antara 51 - 60 sebanyak 4 orang tau $4 \%$.

\section{Karakteristik Responden \\ Berdasarkan Pendidikan}

Hasil analisis karakteristik responden berdasarkan kelompok Pendidikan sebagai berikut:
Tabel 4.3 Karakteristik Responden

Berdasarkan

Pendidikan

\begin{tabular}{|c|c|c|c|}
\hline Pendidikan & Frekuensi & \multirow{2}{*}{\multicolumn{2}{|c|}{$\frac{\text { Persentase }}{3 \%}$}} \\
\hline SD/Sederajat & & & \\
\hline SMP/Sedearjat & & 21 & $21 \%$ \\
\hline SMA/Sederajat & & 60 & $60 \%$ \\
\hline S1 & & 1 & $1 \%$ \\
\hline S2 & & 15 & $15 \%$ \\
\hline Total & & $\begin{array}{l}10 \\
0\end{array}$ & $100 \%$ \\
\hline
\end{tabular}

Sumber: Data OTahan SPSS

Berdasarkan data pada tabel 4.3 atas, dapat diketahui bahwa responden dengan tingkat pendidikan SD/Sederajat sebanyak 3 orang dengan presentase $3 \%$, responden dengan tingkat pendidikan SMP/sederajat sebanyak 21 orang dengan presentase $21 \%$, responden dengan tingkat pendidikan SMA/Sederajat sebanyak 60 orang dengan presentase $60 \%$, responden dengan tingkat pendidikan $\mathrm{S} 1$ sebanyak 1 orang dengan presentase $1 \%$, dan responden dengan tingkat pendidikan S2 sebanyak 15 orang dengan presentase $15 \%$. Berdasarkan data tersebut, dapat disimpulkan bahwa responden yang berpendidikan SMA lebih banyak dengan jumlah 60 orang.

\section{Karakteristik Responden Berdasarkan Pekerjaan}

Hasil analisis karakteristik responden berdasarkan kelompok Pekerjaan sebagai berikut:

Tabel 4.4 Karakteristik Responden Berdasarkan Pekerjaan

\begin{tabular}{|l|c|c|}
\hline \multicolumn{1}{|c|}{ Pekerjaan } & Frekuensi & Persentase \\
\hline Tidak Bekerja & 5 & $5 \%$ \\
\hline Karyawan & 31 & $31 \%$ \\
\hline Wiraswasta & 26 & $26 \%$ \\
\hline PNS & 9 & $9 \%$ \\
\hline Pelajar & 23 & $23 \%$ \\
\hline Lain-lain & 6 & $6 \%$ \\
\hline Total & 100 & $100 \%$ \\
\hline
\end{tabular}

Sumber: Data Olahan SPSS

Berdasarkan data pada Tabel 4.4 dan grafik 4.4 di atas, dapat diketahui bahwa responden yang tidak bekerja sebanyak 5 orang dengan dengan presentase $5 \%$, responden dengan pekerjaan sebagai karyawan sebanyak 31 orang dengan presentase $31 \%$, responden dengan pekerjaan sebagai Wiraswasta sebanyak 26 orang dengan presentase $26 \%$, responden dengan pekerjaan sebagai PNS sebanyak 9 orang dengan presentase 9\%, responden dengan pekerjaan pelajar sebanyak 23 orang dengan presentase $23 \%$ dan responden pekerjaannya selain yang disebutkan dikuesioner sebanyak 6 orang atau $6 \%$. 


\section{Analisis Data Hasil Penelitian Statistik Deskriptif}

Statistik Deskriptif dalam penelitian ini adalah uraian atau penjelasan dari hasil pengumpulan data primer yang telah diisi oleh responden penelitian berupa distribusi masing-masing jawaban dari setiap item pertanyaan yang diajukan kepada responden yatiu dengan melakukan pencarian nilai frekuensi, presentase dan mean terhadap masing-masing variabel yang diteliti yaitu variabel prosedur layanan, jangka waktu, biaya, produk, sarana dan prasarana dan kompetensi petugas yang diukur dengan menggunakan skala likert dan hasilnya dalam bentuk tabel distribusi. Dasar interpretasi skor item dalam variabel penelitian dapat digambarkan sebagai berikut:

Tabel 4.5 Daftar Interpretasi Skor Item Variabel Penelitian

\begin{tabular}{|c|c|c|}
\hline & \\
\hline No & Nilai Skor & Interpretasi \\
\hline 1 & $0<\mathrm{NS} \leq 1$ & $\begin{array}{l}\text { Berada pada daerah } \\
\text { sangat negatif }\end{array}$ \\
\hline 2 & $1<\mathrm{NS} \leq 2$ & $\begin{array}{l}\text { Berada pada daerah } \\
\text { negatif }\end{array}$ \\
\hline 3 & $2<\mathrm{NS}$ & $\begin{array}{l}\text { 3Berada pada daerah } \\
\text { positif }\end{array}$ \\
\hline 4 & $3<\mathrm{NS} \leq 4 \mathrm{H}$ & $\begin{array}{l}\text { Berada pada daerah } \\
\text { sangat positif }\end{array}$ \\
\hline
\end{tabular}

Sumber: Arikunto (2006)

Berikut ini akan dijelaskan mengenaik statistik deskriptif masing-masing variabel Independen dan variabel dependen:

1. Statistik Deskripstif Distribus Frekuensi ItemProsedur Layanan

Tabel 4.6

Distribusi Frekuensi Item Prosedur

Layanan

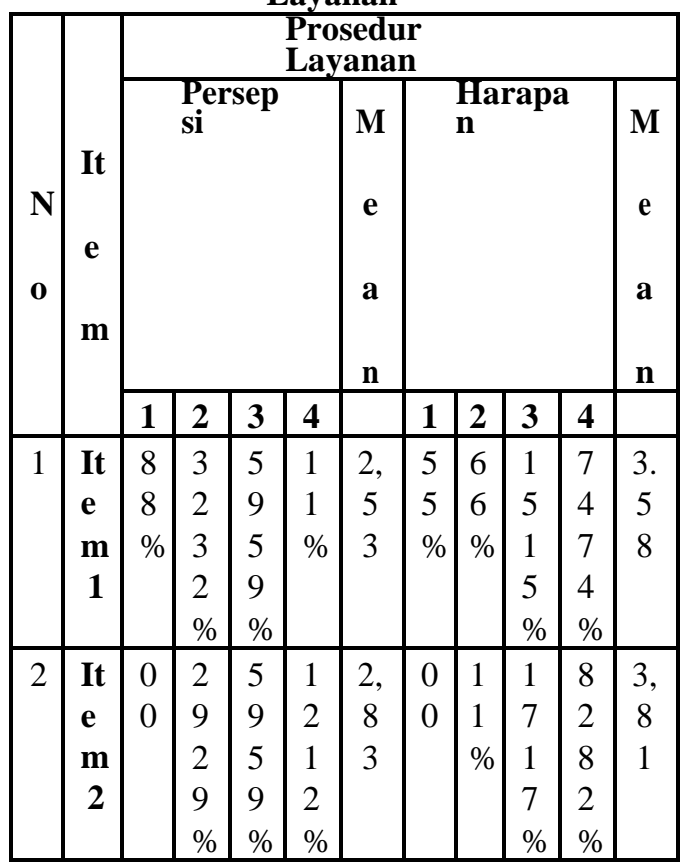

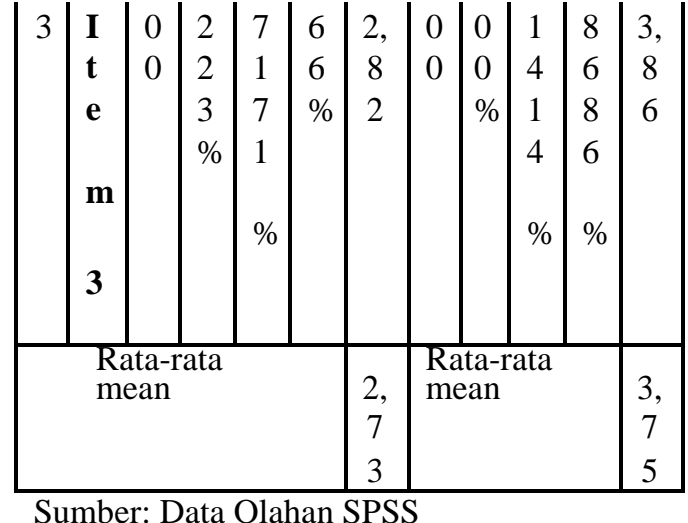

Pada tabel 4.6 diatas dapat diketahui nilai rata-rata variabel Prosedur layanan bedasarkan persepsi konsumen terhadap pengiriman barang kena pajak sebesar 2,73. Rata-rata tertinggi pada pertanyaan item 2 mengenai Kelengkapan persyaratan pengiriman barang kena pajak sedikit dan mudah dengan nilai 2,83, sedangkan yang terendah adalah pada pertanyaan item 1 pernyataan mengenai Prosedur pengiriman barang yang sederhana dengan nilai 2,53. Berdasarkan rata-rata nilai prosedur layanan sebesar 2,73 menggambarkan bahwa persepsi penilaian responden terhadap prosedur layanan yang diberikan kantor Pos terhadap barang kena pajak atau bea cukai berada pada daerah positf atau sudah tergolong baik. Sedangkan kalau dilihat dari harapan konsumen terhadap prosedur layanan barang kena pajak bea dan cukai nilai tertinggi pada item pertanyaan 3 yaitu dengan nilai rata-rata sebesar 3,86 dan pernyataan yang terendah pada pernyataan item 1 dengan nilai rata-rata 3,58. Sedangkan rata-rata dari semua pernyataan berdasarkan harapan sebesar 3,75, ini menggambarkan bahwa harapan konsumen berada pada daerah sangat positif. Kalau dibandingkan antara persepsi dan harapan konsumen mengenai prosedur layanan yang diberikan belum sesuai harapan yang diharapkan, karna nilai harapan lebih besar dibandingkan nilai persepsi. (harapan 3,75> persepsi 2,73)

\section{Statistik Deskripstif Distribusi Frekuensi Item Jangka Waktu}

Daftar Pustaka

Tabel 4.7 Distribusi Frekuensi Item Jangka Waktu

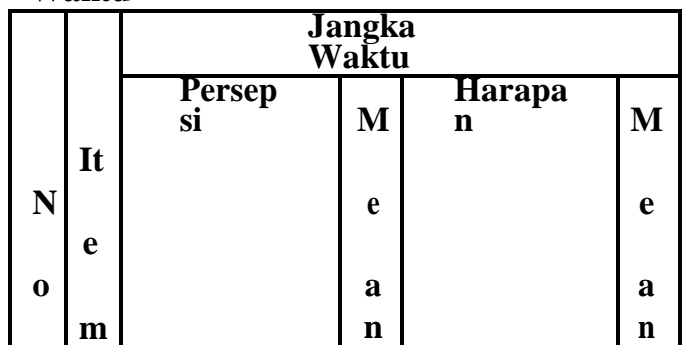




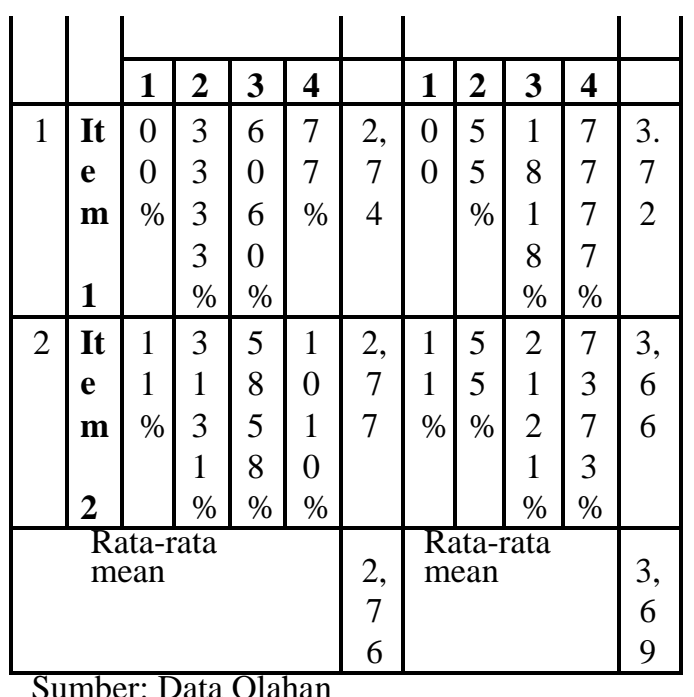

SPSS

Pada tabel 4.7 diatas dapat diketahui nilai rata-rata variabel jangka waktu layanan bedasarkan persepsi konsumen terhadap pengiriman barang kena pajak sebesar 2,76. Rata-rata tertinggi pada pertanyaan item 2 mengenai Jangka waktu layanan pengiriman untuk barang kena pajak sangat cepat dengan nilai 2,77, sedangkan yang terendah adalah pada pertanyaan item 1 pernyataan mengenai waktu untuk pengiriman barang kena pajak sesuai dengan jadwal yang telah ditentukan dengan nilai 2,74. Berdasarkan rata-rata nilai jangka waktu sebesar 2,76 menggambarkan bahwa persepsi penilaian responden mengenai jangka waktu berada pada daerah positf atau sudah tergolong baik. Sedangkan kalau dilihat dari harapan konsumen mengenai jangka waktu nilai tertinggi pada item pertanyaan 1 yaitu dengan nilai rata-rata sebesar 3,72 dan pernyataan yang terendah pada pernyataan item 2 dengan nilai rata-rata 3,66. Sedangkan rata-rata dari semua pernyataan berdasarkan harapan sebesar 3,69, ini menggambarkan bahwa harapan konsumen berada pada daerah sangat positif. Kalau dibandingkan antara persepsi dan harapan konsumen mengenai jangka waktu layanan yang diberikan belum sesuai harapan yang diharapkan, karna nilai harapan lebih besar dibandingkan nilai persepsi. (harapan 3,69> persepsi 2,76)

Statistik Deskripstif Distribusi

Frekuensi Item Biaya

Tabel 4.8 Distribusi Frekuensi Item

Biaya

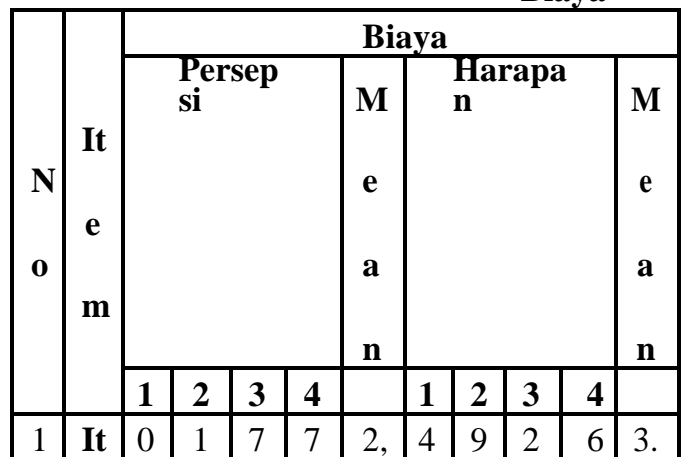

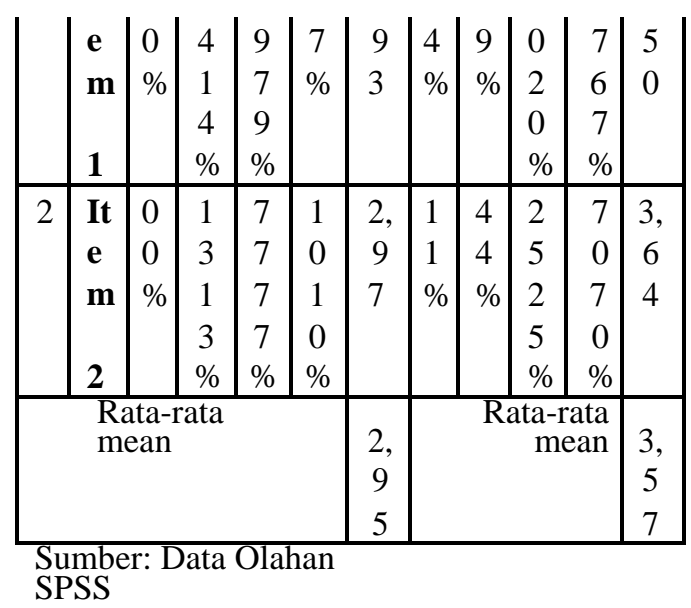

Pada tabel 4.8 diatas dapat diketahui nilai rata-rata variabel biaya bedasarkan persepsi konsumen terhadap pengiriman barang kena pajak sebesar 2,95. Rata-rata tertinggi pada pertanyaan item 2 mengenai biaya yang dikeluarkan sesuai dengan peraturan yang ada dengan nilai 2,97, sedangkan yang terendah adalah pada pertanyaan item 1 pernyataan mengenai biaya yang dikeluarkan sesuai dengan peraturan yang ada dengan nilai 2,64. Berdasarkan rata-rata nilai pada pertanyaan mengenai biaya sebesar 2,95 menggambarkan

bahwa persepsi penilaian responden mengenai pertanyaan yang berkaitan biaya berada pada daerah positf atau sudah tergolong baik. Sedangkan kalau dilihat dari harapan konsumen terhadap pertanyaan mengenai biaya barang kena pajak bea dan cukai nilai tertinggi pada item pertanyaan 2 yaitu dengan nilai rata-rata sebesar 3,64 dan pernyataan yang terendah pada pernyataan item 1 dengan nilai rata-rata 3,50. Sedangkan rata-rata dari semua pernyataan berdasarkan harapan sebesar 3,57, ini menggambarkan bahwa harapan konsumen berada pada daerah sangat positif. Kalau dibandingkan antara persepsi dan harapan konsumen mengenai pertanyaan yang berkaitan biaya belum sesuai harapan yang diharapkan, karna nilai harapan lebih besar dibandingkan nilai persepsi. (harapan 3,57 > persepsi 2,95)

\section{Statistik Deskripstif Distribusi \\ Frekuensi Item Produk}

Tabel 4.9 Distribusi Frekuensi Item

Produk

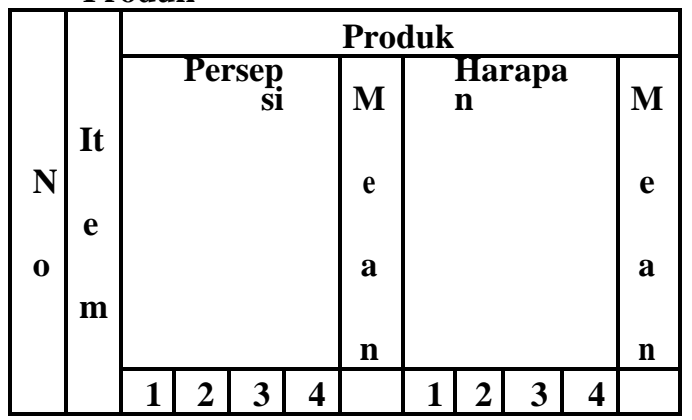




\section{\begin{tabular}{|l|l|l|l|l|l|l|l|l|l|l|l|}
1 & It & 1 & 1 & 7 & 1 & 2, & 0 & 2 & 1 & 8 & 3. \\
\hline
\end{tabular}}

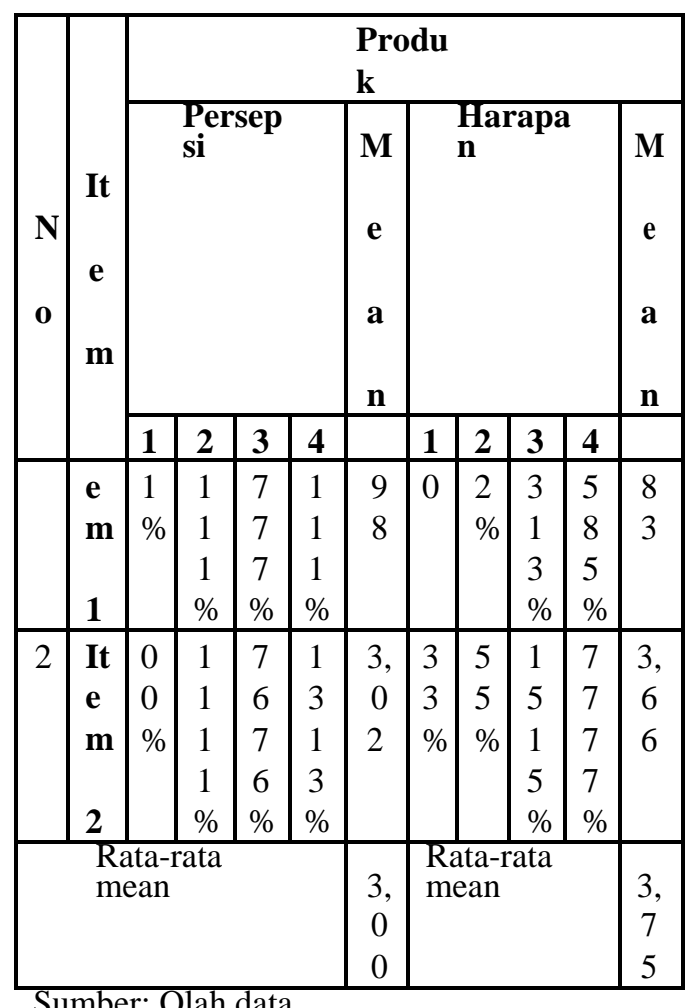

SPSS 17

Pada tabel 4.9 diatas dapat diketahui nilai rata-rata variabel produk bedasarkan persepsi konsumen terhadap pengiriman barang kena pajak sebesar 3,00. Rata-rata tertinggi pada pertanyaan item 2 mengenai produk yang dikenakan pajak sesuai dengan peraturan dengan nilai 3,02 , sedangkan yang terendah adalah pada pertanyaan item 1 pernyataan mengenai transparan terhadap produk yang dikenakan pajak dengan nilai 2,98. Berdasarkan rata-rata nilai pada pertanyaan mengenai produk sebesar 3,00 menggambarkan bahwa persepsi penilaian responden mengenai pertanyaan yang berkaitan produk berada pada daerah sangat positf atau sudah tergolong sangat baik. Sedangkan kalau dilihat dari harapan konsumen terhadap pertanyaan mengenai produk, nilai tertinggi pada item pertanyaan 1 yaitu dengan nilai rata-rata sebesar 3,83 dan pernyataan yang terendah pada pernyataan item 2 dengan nilai rata-rata 3,66. Sedangkan rata-rata dari semua pernyataan berdasarkan

harapan sebesar 3,75, ini menggambarkan bahwa harapan konsumen berada pada daerah sangat positif. Kalau dibandingkan antara persepsi dan harapan konsumen mengenai pertanyaan yang berkaitan produk belum sesuai harapan yang diharapkan, karna nilai harapan lebih besar dibandingkan nilai persepsi. (harapan 3,75 > persepsi 3,00)

Statistik Deskripstif Distribusi Frekuensi Item Sarana dan Prasarana
Tabel 4.10

Distribusi Frekuensi Item Sarana dan

Prasarana

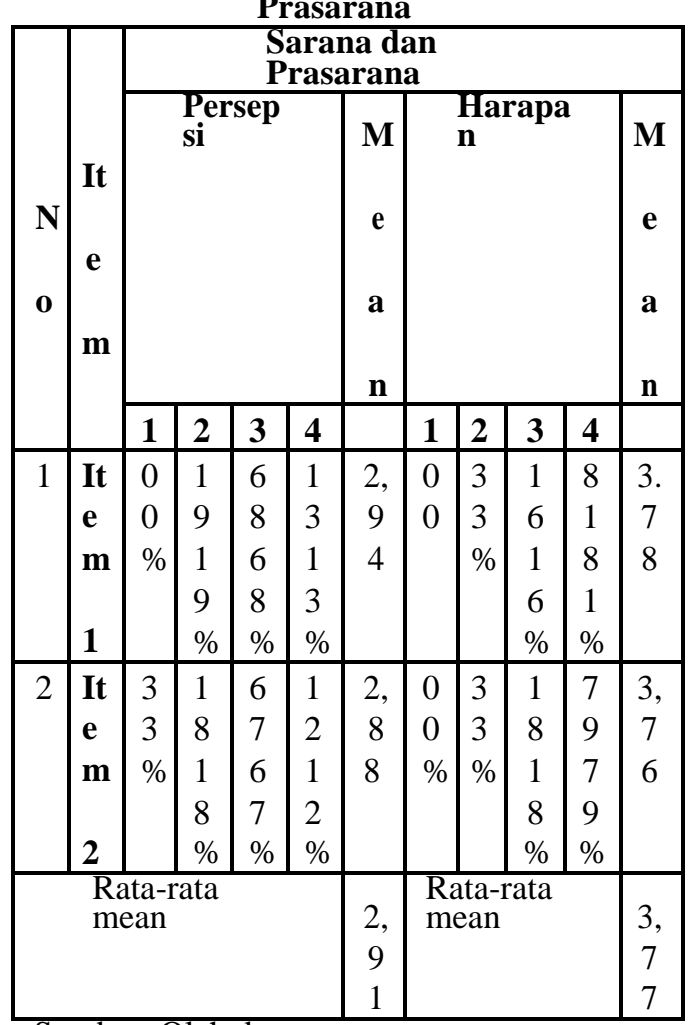

Sumber: Olah data

SPSS 17

Pada tabel 4.10 diatas dapat diketahui nilai ratarata variabel sarana dan prasarana bedasarkan persepsi konsumen terhadap pengiriman barang kena pajak sebesar 2,91. Rata-rata tertinggi pada pertanyaan item 1 mengenai Sarana dan prasarana sangat mendukung dalam proses pengiriman barang dengan nilai 2,94, sedangkan yang terendah adalah pada pertanyaan item 2 pernyataan mengenai Sarana dan prasarana sesuai dengan layanan dengan nilai 2,88. Berdasarkan rata-rata nilai pada pertanyaan mengenai produk sebesar 2,91 menggambarkan bahwa persepsi penilaian responden mengenai pertanyaan yang berkaitan sarana dan prasarana berada pada daerah positf atau sudah tergolong baik. Sedangkan kalau dilihat dari harapan konsumen terhadap pertanyaan mengenai sarana dan prasarana, nilai tertinggi pada item pertanyaan 1 yaitu dengan nilai ratarata sebesar 3,78 dan pernyataan yang terendah pada pernyataan item

2 dengan nilai rata-rata 3,76. Sedangkan ratarata dari semua pernyataan berdasarkan harapan sebesar 3,77, ini menggambarkan bahwa harapan konsumen berada pada daerah sangat positif. Kalau dibandingkan antara persepsi dan harapan konsumen mengenai pertanyaan yang berkaitan sarana dan prasarana belum sesuai harapan yang diharapkan, karna nilai harapan lebih besar dibandingkan nilai persepsi. (harapan 3,77 > persepsi 2,91) 


\section{Statistik Deskripstif Distribusi Frekuensi Item Kompetensi Petugas}

Tabel 4.11 Distribusi Frekuensi Item

\section{Kompetensi}

Petugas

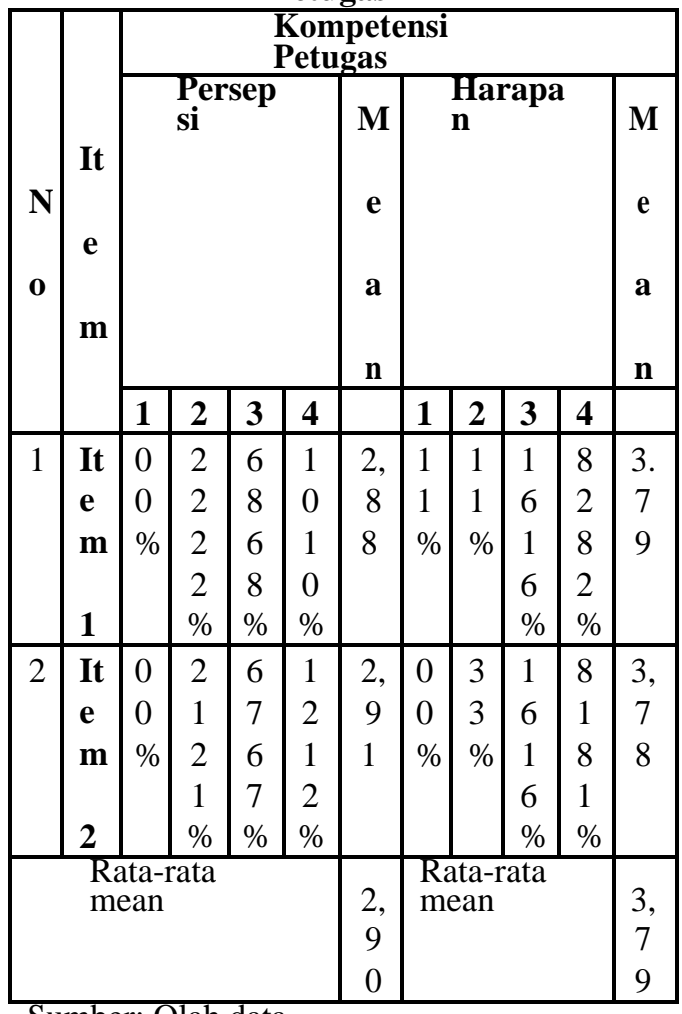

Sumber: Olah data

SPSS 17

Pada tabel 4.11 diatas dapat diketahui nilai rata-rata variabel kompetensi petugas bedasarkan persepsi konsumen terhadap pengiriman barang kena pajak sebesar 2,90. Rata-rata tertinggi pada pertanyaan item 2 mengenai Kepedulian petugas dalam proses pengiriman barang dengan nilai 2,91, sedangkan yang terendah adalah pada pertanyaan item 1 pernyataan mengenai Petugas mengusai terkait prosedur pengiriman barang dengan nilai 2,88. Berdasarkan rata-rata nilai pada pertanyaan mengenai kompetensi petugas sebesar 2,90 menggambarkan bahwa persepsi penilaian responden mengenai

pertanyaan yang berkaitan kompetensi petugas berada pada daerah positf atau sudah tergolong baik. Sedangkan kalau dilihat dari harapan konsumen terhadap pertanyaan mengenai kompetensi petugas, nilai terting8gi pada item pertanyaan 1 yaitu dengan nilai rata-rata sebesar 3,79 dan pernyataan yang terendah pada pernyataan item 2 dengan nilai rata-rata 3,78. Sedangkan ratarata dari semua pernyataan berdasarkan harapan sebesar 3,79, ini menggambarkan bahwa harapan konsumen berada pada daerah sangat positif. Kalau dibandingkan antara persepsi dan harapankonsumenmengenai pertanyaan yang berkaitan kompetensi petugas belum sesuai harapan yang diharapkan, karna nilai harapan lebih besar dibandingkan nilai persepsi. (harapan $3,79>$ persepsi 2,90 )

\section{Kesimpulan}

Berdasarkan hasil penelitian yang telah dilakukan mengenai "Tingkat Kepuasan Konsumen Terhadap Prosedur Layanan Pos Untuk Barang Kena Pajak Dan Atau Bea Cukai Di Kantor Pos Batam Centre, maka penulis menyimpulkan bahwa :

1. Tingkat kepuasan konsumen terhadap prosedur yang ada di Kantor Pos Batam Centre untuk pengiriman barang yang terkena pajak oleh bea cukai rata-rata berada pada daerah positif jika diukur dengan tabel interprestasi, itu artinya konsumen yang memakai jasa kantor pos mendapatkan pelayanan memuaskan dari setiap prosedur yang ada di Kantor Pos Batam Center.

2. Dari beberapa item pertanyaan pada item pertanyaan yang paling rendah persepsi konsumen adalah proses pengiriman yang belum sederhana, tetapi itu hanya konsumen yang baru pertama kali dalam pengiriman barang yang terkena pajak, tetapi disamping itu mereka merasakan pelayanan memuaskan dari petugas yang memberikan alas an kenapa barang mereka dikenakan pajak.

3. Dari penelitian ini menggambarkan bahwa belum semua orang mengetahui jika menggunakan jasa pengiriman dikenakan pajak oleh bea cukai, konsumen hanya mengetahui bahwa yang dikenakan pajak adalah cukup barang elektronik saja. Tetapi barang yang dikenakan pajak adalah barang yang melebihi nilai lima ratus ribu.

\section{Saran}

Adapun saran untuk peneliti sebagai berikut:

1. Bagi penelitian selanjutnya agar dapat memperluas ruang lingkup penelitian demi penyamarataan kualitas pelayanan terhadap prosedur barang yang terkena pajak dalam partai besar.

2. Dalam penelitian ini yang menjadi sasaran hanya konsumen kantor pos secara individu saja, tidak konsumen yang bekerja sama langsung pada kantor pos seperti Perseroan Terbatas atau PT.

\section{Daftar Pustaka}

Fandy, Tjipto. (2006). Manajemen Jasa. Edisi Pertama. Andi.

Ghozali. (2005). Apilkasi Analisis Multivariate Dengan Program SPSS. Semarang. Badan Penerbit Universitas Diponegoro.

Http://bcbatam.beacukai.go.id/kpu-bc-batam/ 
(Diakses pada 10 Januari 2016 pukul 11.30)

Http://www.ombudsman.go.id/index.php/peraturan/ peraturan-presiden.html?download=296:

keputusan-menteri-pan-no-63-tahun-2003

Http://bctemas.beacukai.go.id/wp

content/uploads/2017/03/02bc2017.pdf

Jasfar, Farida. (2006) Manajemen Pendekatas

Jasa Terpadu. Ghalia Indonesia. Bogor.

Kuncoro, Mudrajad. (2004). Otonomi \& Pembangunan

Daerah, Reformasi, Perencanaan, Strategi Dan

Peluang. Jakarta. Erlangga.

Mulyadi, (2010). Sistem Akuntansi, Edisi ke-3, Cetakan ke-5. Salemba Empat, Jakarta.

Nafarin, M. (2009). Penganggaran Perusahaan.

Salemba Empat, Jakarta.

Puspitawati, Lilis. dan Aggadini, S, R. (2011).

Sistem Informasi Akuntansi. Graha Ilmu.

Yogyakarta.

Santoso, M, A. (2014). The Effect Of Free Trade

Zone (FTZ) Implementation In Batam,

Bintan And Karimun Islands (BBK) On Tax Revenue OF Riau Islands Province. Jurnal Manajemen Bisnis, Fakultas Ilmu Administrasi Negara, Universitas Brawijaya, Vol 1, no 1.

Sekaran, Uma. (2006). Research Methods For

Business. Metodologi Penelitian Untuk Bisnis. Jakarta. Salemba Empat.

Simamora, Arta (2007) Kepuasan Penerbit Terhadap Prosedur Dan Kualitas Pelayan International Standard Book Number (ISBN)/KDT Di Perpustakaa Nasional RI.

Tesis, Fakultas Ilmu Sosial dan Politik, Universitas Gadja Mada. Solicha, O. M. N, (2010). Pengaruh Efektifitas E-COMMERCE dan Kebijakan Pertambahan Nilai (PPN) Terhadap Perilaku Konsumen (survey pada konsumen di kota Bandung).

http://jurnal tata cara pengiriman barang kena pajak di Kantor Pos. (Diakses pada 23 Februari 2016 pukul 16:56 WIB) 